\title{
Graduating Senior Assessments Of Curriculum, Educational Outcomes, And The Learning Environment
}

Joseph G. Glynn, (Email: glynn@ canisius.edu), Canisius College

Gregory R. Wood, (Email: gwood@ canisius.edu), Canisius College

\begin{abstract}
Business school faculty and administrations are burdened with seemingly endless directives to update and upgrade curricula and to relate curriculum objectives to outcomes assessment in order to meet demands of accrediting agencies and the business community. The responsibility of assessing outcomes of business school programs is becoming of increasingly paramount importance. This work will describe the efforts of a business school to elicit evaluative opinions of its graduating seniors in an attempt to evaluate the curriculum, its delivery systems, and the overall educational environment.
\end{abstract}

\section{INTRODUCTION}

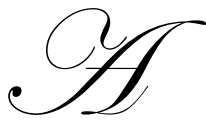

number of environmental forces have intensified the need for business schools to demonstrate appropriate levels of activity in the areas of benchmarking, outcomes measurement, and continuous improvement. Accrediting agencies, employers, parents and government leaders are demanding that institutions of higher learning demonstrate the efficacy of the curricula and courses they offer. Schools of business, in particular, are being challenged to show how their programs are serving the educational needs of their students and the business community. Graduates are expected to have attained the knowledge, skills and competencies that are the explicitly listed goals of the educational process.

This work reports results from on-going surveys of graduating seniors undertaken at a comprehensive midsize private college in an urban area of the northeastern United States. The college has a long standing reputation as a quality institution whose primary focus is teaching. The undergraduate business and MBA programs have been AACSB accredited for about 25 years. Additionally, the college has an excellent reputation and cooperative working relationship with the local business community. The business school has established a number of strategic objectives which include:

1. Provide a high quality business education that delivers appropriately rigorous material in a timely manner.

2. Meet or exceed AACSB standards for accreditation.

3. Provide students with a flexible curriculum that is able to react to changes in the business community.

Information obtained by the surveys is used to help faculty and college administrators assess the degree to which they are achieving these objectives.

\section{BACKGROUND}

\section{Enrollment Challenges}

Over the last decade, demand for an undergraduate business degree has vacillated at the host college. Competition for students has become increasingly intense. The local metropolitan area supports several other 
undergraduate business programs, two of which are also AACSB accredited. The most serious competition is from a large public university with a national reputation. There are several other small to medium-sized undergraduate business programs in public and private colleges in the area. Since all full time faculty are terminally qualified, the program is more costly to students than any of the other programs in the area. The administration is fully committed to growth, so the necessity of expanding the recruitment arena and the need to promote and enhance a quality image are crucial.

\section{Relationship With The Business Community}

As stated above, the host institution enjoys a very positive and mutually beneficial relationship with the business community. Local businesses provide large numbers of internship experiences for undergraduate students on a regular basis. Many of these internships earn academic credit for students, and many pay well in monetary terms. For several reasons, large numbers of graduates are committed to the local geographic area. This reinforces the excellent relationship the college enjoys with the business community and the political establishment as many of the region's "leadership cadre" have graduated from the institution.

\section{Outcomes Assessment}

The modern business world is increasingly characterized by change and uncertainty on many levels. The dynamic environments with respect to domestic issues, globalization, and rapidly changing technologies all command schools of business to design well structured curricula that are flexible, proactive, reactive, and current. The necessity of meeting the educational demands of various stakeholders is becoming increasingly critical as various accrediting bodies revise their standards and expectations in this area. For example, AACSB International, the specialized accrediting agency for collegiate schools of business, requires their members to develop and maintain processes designed to produce stated outcomes, ensure continuous improvement and provide documented evidence that the desired outcomes have been achieved. On a regional basis the Middle States Commission on Higher Education's newly published Characteristics of Excellence in Higher Education, 2002 has a standard (Standard 7) on institutional assessment and a standard (Standard 14) on assessment of student learning (Glynn \& Shick, 2003).

\section{Stakeholders Provide Feedback}

The business school has long been a devotee of the concept of continuous improvement and has advanced along multiple paths to achieve the goals listed above. The School of Business has a strong association with an active Business Advisory Council comprised of about 35 local business leaders. Business Advisory Council members and faculty serve jointly on various Business School committees. There is a healthy environment and ample opportunity for the exchange of ideas. Faculty and the Dean regularly attend AACSB and other curriculum development conferences. The business school enjoys beneficial ties with a very active MBA Alumni Association. The institution also conducts extensive surveys of (a) new MBA matriculates, (b) graduating MBAs, and (c) MBA alumni. Much of what is learned from the business community, MBA students and alumni is of great value in addressing curriculum issues at the undergraduate level.

The school's use of student surveys is consistent with various types of customer satisfaction research methods in other industries. In the field of higher education, others have used survey research to study student/customer choice criteria for selecting colleges (Coccari \& Javalgi, 1995, Conard \& Conard, 2001), student/customer expectations and attitudes (Winzar \& Morley, 1994), student/customer perceptions of teaching procedures (Yau and Quan, 1993) student/customer evaluations of program quality and satisfaction (Zammuto, Keaveney, O'Conner, 1996, Browne et al, 1998) employer evaluations of college programs (Joseph and Joseph, 1997), and employer expectations of student graduating students (Franzack \& Cowles, 1993, Karakaya \& Karakaya, 1996).

This work reports the results of a longitudinal study of seniors at the host institution. The surveys were administered within a week or two of completion of final coursework in both the fall and spring semesters. Survey results are shared with faculty, department chairs, and the dean. Results serve as sources of positive reinforcement as 
well as guides for improvements to classroom presentations, alterations to other delivery systems, and assessments of the curriculum.

\section{RESULTS}

\section{The Survey Instrument}

The surveys have been administered twice annually on a continuous basis since 1996. The surveys are passed out to students in the senior level capstone course that all students should take in their last semester. Instructors collect completed surveys in future classes and put "moderate" pressure on students to comply. Over the years, the return rate has been about 88 percent. The survey instrument is included in the appendix.

The instrument was designed to assess student opinions with respect to:

1. Education Outcomes - Seventeen items related to skills attainment, and

2. Educational Environment - Thirteen items related to the educational atmosphere and delivery systems.

Data for any year include Spring and Fall graduates of that calendar year. For example, results for 2001 include students who graduated in either the Spring of 2001 or the Fall of 2001. This grouping was made because students who graduated in the Fall of 2001 are far more likely to have matriculated as freshmen at the same time as students who graduated in the Spring of 2001 as opposed to students who graduated in the Spring of 2002. For ease of presentation, results in this work will be reported for the five most recent years of complete data, $1999-2003$.

Table 1 merely provides counts of respondents by semester over the analysis sample.

Table 1 - Numbers Of Respondents By Semester

\begin{tabular}{|c|c|c|c|c|c|c|}
\cline { 2 - 8 } \multicolumn{1}{c|}{} & \multicolumn{9}{c|}{ Year Of Graduation } & $\mathbf{2 0 0 2}$ & $\mathbf{2 0 0 3}$ & Total \\
\hline & $\mathbf{1 9 9 9}$ & $\mathbf{2 0 0 0}$ & $\mathbf{2 0 0 1}$ & 134 & 120 & 572 \\
\hline Spring & 91 & 128 & 99 & 23 & 40 & 113 \\
\hline Fall & 15 & 18 & 17 & 157 & 160 & 685 \\
\hline
\end{tabular}

\section{Education Outcomes}

The student respondents were asked to rate how well their college education helped them to develop strengths in the skills areas displayed in Table 2. Students responded by circling a number from -2 (Strongly Disagree) to +2 (Strongly Agree). A "Not Applicable" response was also allowed. The average response for each educational outcomes item by graduation year is presented in Table 2 below.

The results are arranged in descending order by total average (average score over the five year period 19992003). Thus, the item "Analyze Business Problems" attained the highest average score, or the most agreement with the statement that "My education has helped me to better analyze business problems." The ordering of the items reflects the degree to which students feel that the college curriculum has been successful in development of skills. A few groupings of items can be noted. The business curriculum appears to have been highly successful in enhancing analysis and problem-solving skills and understanding of the basic functional areas of business.

The average scores for the middle seven items are almost indistinguishable and range from 1.28 to 1.23. This group contains subgroups which display some commonality:

1. Quantitative/Analytical - Use Computers (1.28), Statistics (1.23), Math (1.23)

2. $\quad$ Environmental/Big Picture - Business Ethics \& Moral Issues (1.25), Global Issues (1.23)

3. Other - Expertise in Major Field (1.28), Oral Communications (1.26). 
The five items at the bottom of the ordered listing have significantly lower averages than the other 13 items. The first three - Cultural Diversity Awareness (0.86), Cultural Diversity Appreciation (0.77), and Table 2 - Education Outcomes Averages By Graduation Year

Table 2 - Education Outcomes Averages By Graduation Year

\begin{tabular}{|c|c|c|c|c|c|c|c|}
\hline & & 1999 & 2000 & $\begin{array}{r}\mathbf{r} \\
\quad \text { of } \\
2001\end{array}$ & $\begin{array}{r}\text { Gradua } \\
2002 \\
\end{array}$ & 2003 & Total \\
\hline \multirow[t]{2}{*}{ Analyze Business Problems } & Mean & 1.61 & 1.64 & 1.73 & 1.67 & 1.80 & 1.69 \\
\hline & $\mathrm{n}$ & 106 & 146 & 115 & 156 & 160 & 683 \\
\hline \multirow[t]{2}{*}{ Business Functional Areas } & Mean & 1.44 & 1.50 & 1.34 & 1.46 & 1.52 & 1.46 \\
\hline & $\mathrm{n}$ & 106 & 145 & 116 & 156 & 160 & 683 \\
\hline \multirow[t]{2}{*}{ Problem-Solving } & Mean & 1.42 & 1.49 & 1.49 & 1.38 & 1.50 & 1.45 \\
\hline & $\mathrm{n}$ & 106 & 146 & 115 & 156 & 159 & 682 \\
\hline \multirow[t]{2}{*}{ Develop Lifelong Learning Skills } & Mean & 1.33 & 1.45 & 1.28 & 1.38 & 1.39 & 1.37 \\
\hline & $\mathrm{n}$ & 106 & 146 & 116 & 157 & 160 & 685 \\
\hline \multirow[t]{2}{*}{ Written Communications } & Mean & 1.23 & 1.38 & 1.30 & 1.44 & 1.44 & 1.37 \\
\hline & $\mathrm{n}$ & 106 & 146 & 116 & 156 & 160 & 684 \\
\hline \multirow[t]{2}{*}{ Use Computers Effectively } & Mean & 1.25 & 1.27 & 1.19 & 1.35 & 1.30 & 1.28 \\
\hline & $\mathrm{n}$ & 105 & 144 & 114 & 156 & 160 & 679 \\
\hline \multirow[t]{2}{*}{ Expertise In Major Field } & Mean & 1.38 & 1.36 & 1.03 & 1.31 & 1.28 & 1.28 \\
\hline & $\mathrm{n}$ & 106 & 146 & 116 & 157 & 160 & 685 \\
\hline \multirow[t]{2}{*}{ Oral Communications } & Mean & 1.19 & 1.26 & 1.08 & 1.34 & 1.38 & 1.26 \\
\hline & $\mathrm{n}$ & 106 & 145 & 116 & 157 & 160 & 684 \\
\hline \multirow[t]{2}{*}{ Business Ethics \& Moral Issues } & Mean & 1.27 & 1.20 & 1.10 & 1.21 & 1.42 & 1.25 \\
\hline & $\mathrm{n}$ & 105 & 146 & 114 & 157 & 160 & 682 \\
\hline \multirow[t]{2}{*}{ Global Issues In Business } & Mean & 1.11 & 1.31 & 1.12 & 1.23 & 1.29 & 1.23 \\
\hline & $\mathrm{n}$ & 106 & 146 & 115 & 157 & 160 & 684 \\
\hline \multirow[t]{2}{*}{ Statistical Concepts } & Mean & 1.20 & 1.24 & 1.16 & 1.25 & 1.28 & 1.23 \\
\hline & $\mathrm{n}$ & 106 & 145 & 116 & 154 & 159 & 680 \\
\hline \multirow[t]{2}{*}{ Math Concepts } & Mean & 1.24 & 1.28 & 1.25 & 1.18 & 1.21 & 1.23 \\
\hline & $\mathrm{n}$ & 105 & 144 & 114 & 155 & 156 & 674 \\
\hline \multirow[t]{2}{*}{ Cultural Diversity Awareness } & Mean & 0.73 & 0.82 & 0.84 & 0.91 & 0.96 & 0.86 \\
\hline & $\mathrm{n}$ & 105 & 145 & 116 & 152 & 160 & 678 \\
\hline \multirow[t]{2}{*}{ Cultural Diversity Appreciation } & Mean & 0.67 & 0.75 & 0.80 & 0.81 & 0.79 & 0.77 \\
\hline & $\mathrm{n}$ & 105 & 144 & 116 & 155 & 158 & 678 \\
\hline \multirow[t]{2}{*}{ Environmental Issues } & Mean & 0.59 & 0.69 & 0.39 & 0.71 & 0.60 & 0.61 \\
\hline & $\mathrm{n}$ & 104 & 145 & 113 & 156 & 159 & 677 \\
\hline \multirow[t]{2}{*}{ Ideas, Events Western Civilization } & Mean & 0.44 & 0.66 & 0.51 & 0.63 & 0.56 & 0.57 \\
\hline & $\mathrm{n}$ & 106 & 139 & 113 & 156 & 156 & 670 \\
\hline \multirow[t]{2}{*}{ Ideas, Events Other Cultures } & Mean & 0.43 & 0.55 & 0.56 & 0.64 & 0.61 & 0.57 \\
\hline & $\mathrm{n}$ & 105 & 143 & 113 & 156 & 157 & 674 \\
\hline
\end{tabular}

Environmental Issues (0.61) - may be described as dimensions of social responsibility. The final two items (the two lowest rated items) are Ideas, Events Western Civilization (0.57) and Ideas, Events Other Cultures (0.57), and seem to fit well under the heading of history. Both the College and the Business School curriculums are responsible for developing strengths and awareness with respect to the three social responsibility items described above. It would appear that the College curriculum is responsible for the delivery of competency on the two history items. While there should be some concern, particularly with respect to the five most lowly rated items, it is noted that all 17 items listed in Table 2 had positive average scores (recall that items were rated on a scale of -2 to +2 ).

In addition to viewing averages, it is often enlightening to compare the percents of respondents who responded positively to those who responded negatively. Recall that each education outcomes item was rated on a 5point scale. More specifically, respondents were afforded the following response options: -2 (Strongly Disagree), -1 (Slightly Disagree), 0 (Neutral), +1 (Slightly Agree), and +2 (Strongly Agree). In order to facilitate comparisons 
between the numbers who disagreed vs. those who agreed, in Table 3 all 0 or neutral responses have been eliminated. The "Disagree" responses (-2s and $-1 \mathrm{~s})$ have been combined and are labeled "Neg."" in Table 3. In like manner, "Agree" responses of +1 and +2 have been combined and are signified by a "Pos.+" label. All numbers presented in Table 3 are percents, and the items have once again been ordered in descending order with those receiving the most positive ratings at the top of the list.

Table 3 - Education Outcomes: Percents Rated Positively/Negatively By Graduation Year

\begin{tabular}{|c|c|c|c|c|c|c|c|}
\hline & & \multirow{2}{*}{1999} & \multirow{2}{*}{\multicolumn{2}{|c|}{$\underset{2001}{\text { Year }}$ of }} & \multicolumn{2}{|c|}{ Graduation } & \multirow[b]{2}{*}{ Total } \\
\hline & & & & & 2002 & 2003 & \\
\hline Analyze Business Problems & $\begin{array}{l}\text { Pos.+ } \\
\text { Neg.- }\end{array}$ & 99.01 .0 & 98.61 .4 & 99.10 .9 & 99.40 .6 & $\begin{array}{c}100.0 \\
0.0\end{array}$ & 99.30 .7 \\
\hline Problem-Solving & $\begin{array}{l}\text { Pos.t } \\
\text { Neg.- }\end{array}$ & 97.03 .0 & 99.30 .7 & 99.10 .9 & 98.02 .0 & 99.40 .6 & 98.61 .4 \\
\hline Develop Lifelong Learning Skills & $\begin{array}{l}\text { Pos.+ } \\
\text { Neg.- }\end{array}$ & 96.83 .2 & 99.30 .7 & 94.35 .7 & $\begin{array}{c}100.0 \\
0.0\end{array}$ & 97.42 .6 & 97.82 .2 \\
\hline Business Functional Areas & $\begin{array}{l}\text { Pos.+ } \\
\text { Neg.- }\end{array}$ & 95.24 .8 & $\begin{array}{c}100.0 \\
0.0 \\
\end{array}$ & 95.64 .4 & 98.71 .3 & 96.83 .2 & 97.42 .6 \\
\hline Written Communications & $\begin{array}{l}\text { Pos.t } \\
\text { Neg.- }\end{array}$ & 92.08 .0 & 98.51 .5 & 98.21 .8 & 98.61 .4 & 97.42 .6 & 97.22 .8 \\
\hline Math Concepts & $\begin{array}{l}\text { Pos.+ } \\
\text { Neg.- }\end{array}$ & 96.83 .2 & 98.41 .6 & 96.23 .8 & 96.23 .8 & 97.03 .0 & 96.93 .1 \\
\hline Oral Communications & $\begin{array}{l}\text { Pos.+ } \\
\text { Neg.- }\end{array}$ & 94.95 .1 & 98.51 .5 & 90.79 .3 & 96.73 .3 & 96.73 .3 & 95.84 .2 \\
\hline Global Issues In Business & $\begin{array}{l}\text { Pos.+ } \\
\text { Neg.- }\end{array}$ & 91.78 .3 & 99.30 .7 & 94.15 .9 & 95.05 .0 & 97.32 .7 & 95.84 .2 \\
\hline Business Ethics \& Moral Issues & $\begin{array}{l}\text { Pos.+ } \\
\text { Neg.- }\end{array}$ & 94.75 .3 & 95.54 .5 & 91.98 .1 & 94.45 .6 & 97.32 .7 & 95.05 .0 \\
\hline Use Computers Effectively & $\begin{array}{l}\text { Pos.+ } \\
\text { Neg.- }\end{array}$ & 93.66 .4 & 92.57 .5 & 94.85 .2 & 97.82 .2 & 95.74 .3 & 95.05 .0 \\
\hline Statistical Concepts & $\begin{array}{l}\text { Pos.+ } \\
\text { Neg.- }\end{array}$ & 95.84 .2 & 95.44 .6 & 91.58 .5 & 96.43 .6 & 94.65 .4 & 94.85 .2 \\
\hline Expertise In Major Field & $\begin{array}{l}\text { Pos.t } \\
\text { Neg.- }\end{array}$ & 96.04 .0 & 95.64 .4 & $\begin{array}{l}85.6 \\
14.4 \\
\end{array}$ & 95.84 .2 & 91.98 .1 & 93.16 .9 \\
\hline Cultural Diversity Awareness & $\begin{array}{l}\text { Pos.+ } \\
\text { Neg.- }\end{array}$ & $\begin{array}{l}85.0 \\
15.0 \\
\end{array}$ & $\begin{array}{l}87.5 \\
12.5 \\
\end{array}$ & $\begin{array}{l}90.0 \\
10.0 \\
\end{array}$ & $\begin{array}{l}89.2 \\
10.8 \\
\end{array}$ & $\begin{array}{l}87.6 \\
12.4 \\
\end{array}$ & $\begin{array}{l}87.9 \\
12.1 \\
\end{array}$ \\
\hline Cultural Diversity Appreciation & $\begin{array}{l}\text { Pos.+ } \\
\text { Neg.- }\end{array}$ & $\begin{array}{l}82.1 \\
17.9\end{array}$ & $\begin{array}{l}86.4 \\
13.6\end{array}$ & $\begin{array}{l}89.6 \\
10.4\end{array}$ & $\begin{array}{l}87.4 \\
12.6\end{array}$ & $\begin{array}{l}88.8 \\
11.2\end{array}$ & $\begin{array}{l}87.0 \\
13.0\end{array}$ \\
\hline Ideas, Events Western Civilization & $\begin{array}{l}\text { Pos.+ } \\
\text { Neg.- }\end{array}$ & $\begin{array}{l}77.0 \\
23.0 \\
\end{array}$ & $\begin{array}{l}85.2 \\
14.8 \\
\end{array}$ & $\begin{array}{l}82.3 \\
17.7 \\
\end{array}$ & $\begin{array}{l}84.4 \\
15.6 \\
\end{array}$ & $\begin{array}{l}82.2 \\
17.8 \\
\end{array}$ & $\begin{array}{l}82.7 \\
17.3 \\
\end{array}$ \\
\hline Environmental Issues & $\begin{array}{l}\text { Pos.+ } \\
\text { Neg.- }\end{array}$ & $\begin{array}{l}74.7 \\
25.3 \\
\end{array}$ & $\begin{array}{l}86.5 \\
13.5 \\
\end{array}$ & $\begin{array}{l}70.2 \\
29.8 \\
\end{array}$ & $\begin{array}{l}85.1 \\
14.9 \\
\end{array}$ & $\begin{array}{l}80.9 \\
19.1 \\
\end{array}$ & $\begin{array}{l}80.2 \\
19.8 \\
\end{array}$ \\
\hline Ideas, Events Other Cultures & $\begin{array}{l}\text { Pos.+ } \\
\text { Neg.- }\end{array}$ & $\begin{array}{l}73.8 \\
26.2 \\
\end{array}$ & $\begin{array}{l}76.8 \\
23.2 \\
\end{array}$ & $\begin{array}{l}80.2 \\
19.8 \\
\end{array}$ & $\begin{array}{l}82.6 \\
17.4\end{array}$ & $\begin{array}{l}82.6 \\
17.4\end{array}$ & $\begin{array}{l}79.5 \\
20.5 \\
\end{array}$ \\
\hline
\end{tabular}

As should be expected, the ordering or pattern of Table 3 mirrors the pattern of Table 2. The analysis and problem-solving skills and understanding business functional areas again scored highly, and the mid-range items were also the same as in Table 2. The items clearly receiving the lowest positive percents are the same five lowly rated items in Table 2, the three social responsibility and two history items.

\section{Educational Environment}

The student respondents were asked to evaluate their college experience on 13 dimensions related to educational environment. Once again, students responded by circling a number from -2 (Strongly Disagree) to +2 (Strongly Agree). A "Not Applicable" response was also allowed. The average responses by graduation year for these educational environment items are presented in descending order in Table 4 below. 
Table 4 - Educational Environment Averages By Graduation Year

\begin{tabular}{|c|c|c|c|c|c|c|c|}
\hline & & & & & Gradu & & \\
\hline & & 1999 & 2000 & 2001 & 2002 & 2003 & Total \\
\hline Prof's Business Experience Valuable & Mean & 1.46 & 1.44 & 1.63 & 1.48 & 1.55 & 1.51 \\
\hline & $\mathrm{n}$ & 106 & 146 & 115 & 157 & 158 & 682 \\
\hline Small Class Size & Mean & 1.30 & 1.51 & 1.42 & 1.47 & 1.38 & 1.43 \\
\hline & $\mathrm{n}$ & 106 & 146 & 116 & 157 & 159 & 684 \\
\hline Analytical Assignments Valuable & Mean & 1.39 & 1.34 & 1.42 & 1.46 & 1.46 & 1.42 \\
\hline & $\mathrm{n}$ & 106 & 146 & 116 & 157 & 159 & 684 \\
\hline Professors Committed To Education & Mean & 1.26 & 1.24 & 1.29 & 1.36 & 1.35 & 1.31 \\
\hline & $\mathrm{n}$ & 106 & 146 & 116 & 157 & 159 & 684 \\
\hline Adequacy Of Computer Software & Mean & 0.89 & 1.15 & 1.23 & 1.32 & 1.45 & 1.23 \\
\hline & $\mathrm{n}$ & 104 & 144 & 115 & 154 & 157 & 674 \\
\hline Adequacy Of Library Hours & Mean & 1.01 & 1.10 & 1.15 & 1.13 & 1.22 & 1.13 \\
\hline & $\mathrm{n}$ & 106 & 145 & 115 & 156 & 158 & 680 \\
\hline Adequacy Of Computer Hardware & Mean & 0.70 & 1.04 & 1.09 & 1.30 & 1.29 & 1.12 \\
\hline & $\mathrm{n}$ & 105 & 145 & 115 & 155 & 158 & 678 \\
\hline Group Projects Valuable & Mean & 1.13 & 1.14 & 0.98 & 0.97 & 1.20 & 1.09 \\
\hline & $\mathrm{n}$ & 106 & 146 & 116 & 157 & 158 & 683 \\
\hline Writing Assignments Valuable & Mean & 0.92 & 1.10 & 0.97 & 0.98 & 1.08 & 1.02 \\
\hline & $\mathrm{n}$ & 105 & 145 & 116 & 156 & 159 & 681 \\
\hline Adequacy Of Library Resources & Mean & 0.57 & 0.96 & 1.01 & 1.08 & 1.06 & 0.96 \\
\hline & $\mathrm{n}$ & 106 & 145 & 115 & 156 & 159 & 681 \\
\hline Prof's Research Valuable In Class & Mean & 0.70 & 0.83 & 0.94 & 0.98 & 1.06 & 0.92 \\
\hline & $\mathrm{n}$ & 100 & 138 & 109 & 147 & 155 & 649 \\
\hline Adequacy Of Computer Lab Hours & Mean & 0.50 & 0.76 & 0.80 & 1.10 & 1.15 & 0.90 \\
\hline & $\mathrm{n}$ & 105 & 143 & 113 & 153 & 157 & 671 \\
\hline Placement Center Valuable & Mean & 0.71 & 0.58 & 0.63 & 0.47 & 0.11 & 0.47 \\
\hline & $\mathrm{n}$ & 99 & 130 & 104 & 135 & 145 & 613 \\
\hline
\end{tabular}

The four highest rated items divulge that students are very satisfied with their professors [Prof's Business Experience Valuable (1.51) and Professors Committed To Education (1.31)], with the Small Class Size (1.43) and with Analytical Assignments (1.42). The Adequacies of Computer Hardware (1.12) and Software (1.23) were rated in mid-range, while Adequacy of Computer Lab Hours (0.90) was rated lower. The library experienced a different result than computers. Adequacy of Library Hours (1.13) scored higher than Adequacy of Library Resources (0.96). The value of the Placement Center (0.47) was rated significantly lower than any other item. This low rating may be related to problems in the Placement Center or a sluggish local economy or something else. Investigation into the cause(s) of this low rating is warranted.

Recall that Table 3 compared the percents of respondents who responded positively to percents who responded negatively with respect to education outcomes issues, Table 5 will display similar statistics for percents of student respondents who rated the educational environment items positively or negatively. Once again, all of the numbers presented in Table 5 are percents, and the items are listed in descending order on the basis of total positive percents.

\section{Education Outcomes by Business Major and Gender}

Student responses should be expected to vary across business majors. How, if at all, might gender affect responses? These issues will be examined, and the results are shown in Tables 6, 7, and 8. These tables present similar information - there are three tables only for ease of presentation. Table 6 reports results for accounting and finance majors, Table 7 information systems and management majors, and Table 8 for marketing majors and totals for all majors. The items are not ordered in these tables - they merely appear in the same order they appeared on the survey. The careful reader will note that the total for all majors exceeds the sum of respondents across the five majors depicted individually in Tables $6-8$. This is because the total for all majors includes many students not represented 
in the five majors. There are dual majors and a few majors such as entrepreneurship and hotel management that are included in the totals for all majors.

Table 5 - Educational Environment: Percents Rated Positively/Negatively By Graduation Year

\begin{tabular}{|c|c|c|c|c|c|c|c|}
\hline & & 1999 & $2000^{Y}$ & $\begin{array}{r}\text { of } \\
\end{array}$ & Graduat & & T \\
\hline Prof's Business Experience Valuable & $\begin{array}{l}\text { Pos.+ } \\
\text { Neg.- }\end{array}$ & 98.02 .0 & 98.51 .5 & 98.21 .8 & 97.42 .6 & 98.71 .3 & 98.11 .9 \\
\hline Analytical Assignments Valuable & $\begin{array}{l}\text { Pos.+ } \\
\text { Neg.- }\end{array}$ & 97.03 .0 & 94.45 .6 & 95.54 .5 & 97.32 .7 & 95.44 .6 & 95.94 .1 \\
\hline Professors Committed To Education & $\begin{array}{l}\text { Pos.+ } \\
\text { Neg.- }\end{array}$ & 94.95 .1 & 92.67 .4 & 95.44 .6 & 97.92 .1 & 93.56 .5 & 94.95 .1 \\
\hline Small Class Size & $\begin{array}{l}\text { Pos.+ } \\
\text { Neg.- }\end{array}$ & 93.16 .9 & $\begin{array}{l}89.3 \\
10.7\end{array}$ & 96.43 .6 & 96.13 .9 & 94.75 .3 & 93.96 .1 \\
\hline Adequacy Of Computer Software & $\begin{array}{l}\text { Pos.+ } \\
\text { Neg.- }\end{array}$ & $\begin{array}{l}82.5 \\
17.5\end{array}$ & $\begin{array}{l}87.9 \\
12.1\end{array}$ & 92.57 .5 & 94.45 .6 & 96.63 .4 & 91.48 .6 \\
\hline Writing Assignments Valuable & $\begin{array}{l}\text { Pos.+ } \\
\text { Neg.- }\end{array}$ & $\begin{array}{l}87.9 \\
12.1\end{array}$ & 92.47 .6 & $\begin{array}{l}89.1 \\
10.9\end{array}$ & 91.38 .7 & 91.58 .5 & 90.79 .3 \\
\hline Prof's Research Valuable In Class & $\begin{array}{l}\text { Pos.+ } \\
\text { Neg.- }\end{array}$ & $\begin{array}{l}82.1 \\
17.9\end{array}$ & $\begin{array}{l}87.6 \\
12.4\end{array}$ & $\begin{array}{l}88.6 \\
11.4\end{array}$ & 90.29 .8 & 93.07 .0 & $\begin{array}{l}88.8 \\
11.2\end{array}$ \\
\hline Group Projects Valuable & $\begin{array}{l}\text { Pos.+ } \\
\text { Neg.- }\end{array}$ & 90.59 .5 & 90.59 .5 & $\begin{array}{l}84.8 \\
15.2 \\
\end{array}$ & $\begin{array}{l}85.2 \\
14.8 \\
\end{array}$ & 90.39 .7 & $\begin{array}{l}88.3 \\
11.7 \\
\end{array}$ \\
\hline Adequacy Of Computer Hardware & $\begin{array}{l}\text { Pos.+ } \\
\text { Neg.- }\end{array}$ & $\begin{array}{l}76.3 \\
23.7 \\
\end{array}$ & $\begin{array}{l}84.6 \\
15.4 \\
\end{array}$ & $\begin{array}{l}86.9 \\
13.1\end{array}$ & 93.16 .9 & 90.59 .5 & $\begin{array}{l}87.0 \\
13.0\end{array}$ \\
\hline Adequacy Of Library Resources & $\begin{array}{l}\text { Pos.+ } \\
\text { Neg.- }\end{array}$ & $\begin{array}{l}71.1 \\
28.9\end{array}$ & $\begin{array}{l}85.4 \\
14.6\end{array}$ & $\begin{array}{l}89.8 \\
10.2\end{array}$ & 92.77 .3 & $\begin{array}{l}88.2 \\
11.8\end{array}$ & $\begin{array}{l}86.3 \\
13.7\end{array}$ \\
\hline Adequacy Of Library Hours & $\begin{array}{l}\text { Pos.+ } \\
\text { Neg.- }\end{array}$ & $\begin{array}{l}85.0 \\
15.0\end{array}$ & $\begin{array}{l}84.1 \\
15.9\end{array}$ & $\begin{array}{l}86.9 \\
13.1\end{array}$ & $\begin{array}{l}86.7 \\
13.3\end{array}$ & $\begin{array}{l}87.5 \\
12.5\end{array}$ & $\begin{array}{l}86.1 \\
13.9\end{array}$ \\
\hline Adequacy Of Computer Lab Hours & $\begin{array}{l}\text { Pos.+ } \\
\text { Neg.- }\end{array}$ & $\begin{array}{l}71.6 \\
28.4\end{array}$ & $\begin{array}{l}77.9 \\
22.1\end{array}$ & $\begin{array}{l}77.6 \\
22.4\end{array}$ & $\begin{array}{l}87.7 \\
12.3\end{array}$ & $\begin{array}{l}89.6 \\
10.4\end{array}$ & $\begin{array}{l}81.8 \\
18.2\end{array}$ \\
\hline Placement Center Valuable & $\begin{array}{l}\text { Pos.+ } \\
\text { Neg.- }\end{array}$ & $\begin{array}{l}85.1 \\
14.9\end{array}$ & $\begin{array}{l}73.3 \\
26.7\end{array}$ & $\begin{array}{l}81.9 \\
18.1\end{array}$ & $\begin{array}{l}70.5 \\
29.5\end{array}$ & $\begin{array}{l}57.5 \\
42.5\end{array}$ & $\begin{array}{l}72.3 \\
27.7\end{array}$ \\
\hline
\end{tabular}

Asterisks appear in Tables 6-8 where statistically significant differences were noted between female and male students on ratings of how successfully strengths were developed in the areas included. There are not many instances of statistically significant differences between the men and women, but some interesting patterns are nonetheless apparent. In Table 6, for Accounting students, females had higher ratings than males on 13 of the 17 items including all five of the items that displayed statistically significant differences - Written Communications, Use Computers Effectively, Cultural Diversity Appreciation, Environmental Issues, and Global Issues In Business. There was no evidence of statistically significant differences between female and male ratings among Finance students, and neither female nor male students dominated the positive ratings as was the case among Accounting students.

There were no statistically significant differences in the ratings by females and males among Information Systems students. Among Management students, only two cases of statistically significant differences between ratings by female and male students emerged (Environmental Issues and Global Issues In Business), and only one instance among Marketing students (Ideas, Events Other Cultures). The authors of this work will not be so impudent as to attempt to interpret the data for the various majors. We will merely point out that there is interesting information in Tables 6, 7, and 8. We recommend that the data for any department be scrutinized within the department, but that all data be made available to all departments. For example, it is useful for the Information Systems Department to know how Marketing students, and the students of all other departments, compare in ratings of these academic outcomes measures to their own students. 
Table 6 - Education Outcomes Averages by Major and Gender

\begin{tabular}{|c|c|c|c|c|c|c|c|}
\hline & & \multicolumn{4}{|c|}{ Accounting } & \multicolumn{2}{|l|}{ Finance } \\
\hline & & Female & Male & Total & Female & Male & Total \\
\hline \multirow[t]{2}{*}{ Oral Communications } & Mean & 1.18 & 1.24 & 1.21 & 1.15 & 1.20 & 1.18 \\
\hline & $\mathrm{n}$ & 40 & 37 & 77 & 53 & 93 & 146 \\
\hline \multirow[t]{2}{*}{ Written Communications } & Mean & $1.33 *$ & $0.89 *$ & 1.12 & 1.30 & 1.28 & 1.29 \\
\hline & $\mathrm{n}$ & 40 & 37 & 77 & 54 & 93 & 147 \\
\hline Analyze Business & Mean & 1.70 & 1.57 & 1.64 & 1.67 & 1.73 & 1.71 \\
\hline Problems & $\mathrm{n}$ & 40 & 37 & 77 & 54 & 93 & 147 \\
\hline \multirow{2}{*}{ Problem-Solving } & Mean & 1.55 & 1.32 & 1.44 & 1.37 & 1.52 & 1.47 \\
\hline & $\mathrm{n}$ & 40 & 37 & 77 & 54 & 92 & 146 \\
\hline \multirow[t]{2}{*}{ Math Concepts } & Mean & 1.33 & 1.03 & 1.18 & 1.44 & 1.32 & 1.37 \\
\hline & $\mathrm{n}$ & 40 & 36 & 76 & 54 & 91 & 145 \\
\hline \multirow[t]{2}{*}{ Statistical Concepts } & Mean & 1.10 & 1.30 & 1.19 & 1.57 & 1.34 & 1.43 \\
\hline & $\mathrm{n}$ & 40 & 37 & 77 & 54 & 93 & 147 \\
\hline Use Computers & Mean & $1.43 * *$ & $0.81 * *$ & 1.13 & 1.46 & 1.34 & 1.39 \\
\hline Effectively & $\mathrm{n}$ & 40 & 36 & 76 & 54 & 93 & 147 \\
\hline Cultural Diversity & Mean & 0.83 & 0.43 & 0.64 & 0.78 & 0.77 & 0.77 \\
\hline Awareness & $\mathrm{n}$ & 40 & 37 & 77 & 54 & 91 & 145 \\
\hline Cultural Diversity & Mean & $0.73 *$ & $0.27 *$ & 0.51 & 0.77 & 0.61 & 0.67 \\
\hline Appreciation & $\mathrm{n}$ & 40 & 37 & 77 & 53 & 92 & 145 \\
\hline Ideas, Events Western & Mean & 0.48 & 0.27 & 0.38 & 0.38 & 0.64 & 0.55 \\
\hline Civilization & $\mathrm{n}$ & 40 & 37 & 77 & 53 & 90 & 143 \\
\hline Ideas, Events & Mean & 0.51 & 0.14 & 0.33 & 0.56 & 0.57 & 0.56 \\
\hline Other Cultures & $\mathrm{n}$ & 39 & 37 & 76 & 54 & 92 & 146 \\
\hline Business Ethics \& Moral & Mean & 1.33 & 1.05 & 1.20 & 1.09 & 1.17 & 1.14 \\
\hline Issues & $\mathrm{n}$ & 39 & 37 & 76 & 54 & 93 & 147 \\
\hline Environmental & Mean & $0.54 *$ & $0.06^{*}$ & 0.31 & 0.61 & 0.59 & 0.60 \\
\hline Issues & $\mathrm{n}$ & 39 & 36 & 75 & 54 & 91 & 145 \\
\hline Global Issues & Mean & $1.10^{*}$ & $0.70 *$ & 0.91 & 1.13 & 1.19 & 1.17 \\
\hline In Business & $\mathrm{n}$ & 39 & 37 & 76 & 54 & 93 & 147 \\
\hline Develop Lifelong & Mean & 1.20 & 1.27 & 1.23 & 1.48 & 1.29 & 1.36 \\
\hline Learning Skills & $\mathrm{n}$ & 40 & 37 & 77 & 54 & 93 & 147 \\
\hline Business & Mean & 1.35 & 1.53 & 1.43 & 1.56 & 1.49 & 1.52 \\
\hline Functional Areas & $\mathrm{n}$ & 40 & 36 & 76 & 54 & 93 & 147 \\
\hline Expertise In & Mean & 1.62 & 1.51 & 1.57 & 1.33 & 1.39 & 1.37 \\
\hline Major Field & $\mathrm{n}$ & 40 & 37 & 77 & 54 & 93 & 147 \\
\hline
\end{tabular}

$*$ Difference significant at $\mathrm{p}<0.05$

** Difference significant at $\mathrm{p}<0.01$

\section{CONCLUSIONS}

The Graduating Seniors Survey has afforded the School of Business a vehicle to assess the effectiveness of its programs and educational enhancement initiatives with respect to the specific items listed under Educational Outcomes and Educational Environment. These data allow the School of Business to draw several conclusions with regard to the research objectives previously listed. Those research objectives and conclusions are listed below.

\section{Ability To Provide A High Quality Business Education That Delivers Appropriately Rigorous Material In A Timely Manner}

Students have been very consistent over time in giving extremely positive assessments with respect to the achievement of most of the skills and comfort with the knowledge-based areas of the Education Outcomes section of the survey (see Tables 2 and 3). We are pleased that the items Analyze Business Problems, Business Functional Areas, and Problem-Solving have been consistently rated highest. Students clearly feel that their undergraduate experience provides them with appropriate development of written and oral communications skills, lifelong learning 
Table 7 - Education Outcomes Averages by Major and Gender

\begin{tabular}{|c|c|c|c|c|c|c|c|}
\hline & & \multicolumn{3}{|c|}{ Information Systems } & \multicolumn{3}{|c|}{ Management } \\
\hline & & Female & Male & Total & Female & Male & Total \\
\hline Oral Communications & $\begin{array}{l}\text { Mean } \\
\mathrm{n}\end{array}$ & $\begin{array}{c}1.18 \\
28 \\
\end{array}$ & $\begin{array}{c}1.21 \\
52 \\
\end{array}$ & $\begin{array}{c}1.20 \\
80 \\
\end{array}$ & $\begin{array}{c}1.48 \\
82 \\
\end{array}$ & $\begin{array}{l}1.40 \\
124 \\
\end{array}$ & $\begin{array}{l}1.43 \\
206 \\
\end{array}$ \\
\hline $\begin{array}{l}\text { Written } \\
\text { Communications }\end{array}$ & $\begin{array}{l}\text { Mean } \\
\mathrm{n}\end{array}$ & $\begin{array}{c}1.50 \\
28\end{array}$ & $\begin{array}{c}1.27 \\
51\end{array}$ & $\begin{array}{c}1.35 \\
79\end{array}$ & $\begin{array}{c}1.52 \\
82\end{array}$ & $\begin{array}{l}1.46 \\
124\end{array}$ & $\begin{array}{l}1.49 \\
206\end{array}$ \\
\hline $\begin{array}{l}\text { Analyze Business } \\
\text { Problems }\end{array}$ & $\begin{array}{l}\text { Mean } \\
\mathrm{n}\end{array}$ & $\begin{array}{c}1.71 \\
28\end{array}$ & $\begin{array}{c}1.58 \\
50\end{array}$ & $\begin{array}{c}1.63 \\
78\end{array}$ & $\begin{array}{c}1.74 \\
82\end{array}$ & $\begin{array}{l}1.71 \\
124 \\
\end{array}$ & $\begin{array}{l}1.72 \\
206\end{array}$ \\
\hline Problem-Solving & $\begin{array}{l}\text { Mean } \\
\mathrm{n}\end{array}$ & $\begin{array}{c}1.43 \\
28\end{array}$ & $\begin{array}{c}1.38 \\
52\end{array}$ & $\begin{array}{c}1.40 \\
80\end{array}$ & $\begin{array}{c}1.46 \\
81\end{array}$ & $\begin{array}{l}1.44 \\
123\end{array}$ & $\begin{array}{l}1.45 \\
204\end{array}$ \\
\hline Math Concepts & $\begin{array}{l}\text { Mean } \\
\mathrm{n}\end{array}$ & $\begin{array}{c}1.25 \\
28\end{array}$ & $\begin{array}{c}1.08 \\
50 \\
\end{array}$ & $\begin{array}{c}1.14 \\
78 \\
\end{array}$ & $\begin{array}{c}1.17 \\
81\end{array}$ & $\begin{array}{l}1.17 \\
122 \\
\end{array}$ & $\begin{array}{l}1.17 \\
203\end{array}$ \\
\hline Statistical Concepts & $\begin{array}{l}\text { Mean } \\
\mathrm{n}\end{array}$ & $\begin{array}{c}1.39 \\
28 \\
\end{array}$ & $\begin{array}{c}1.20 \\
50 \\
\end{array}$ & $\begin{array}{c}1.27 \\
78 \\
\end{array}$ & $\begin{array}{c}1.06 \\
82 \\
\end{array}$ & $\begin{array}{l}1.18 \\
123 \\
\end{array}$ & $\begin{array}{l}1.13 \\
205 \\
\end{array}$ \\
\hline $\begin{array}{l}\text { Use Computers } \\
\text { Effectively }\end{array}$ & $\begin{array}{l}\text { Mean } \\
\mathrm{n}\end{array}$ & $\begin{array}{c}1.54 \\
28 \\
\end{array}$ & $\begin{array}{c}1.24 \\
51\end{array}$ & $\begin{array}{c}1.34 \\
79 \\
\end{array}$ & $\begin{array}{c}1.30 \\
81 \\
\end{array}$ & $\begin{array}{l}1.18 \\
123 \\
\end{array}$ & $\begin{array}{l}1.23 \\
204 \\
\end{array}$ \\
\hline $\begin{array}{l}\text { Cultural Diversity } \\
\text { Awareness }\end{array}$ & $\begin{array}{l}\text { Mean } \\
\mathrm{n}\end{array}$ & $\begin{array}{c}0.86 \\
28\end{array}$ & $\begin{array}{c}0.63 \\
52\end{array}$ & $\begin{array}{c}0.71 \\
80\end{array}$ & $\begin{array}{c}0.95 \\
80\end{array}$ & $\begin{array}{l}0.99 \\
122\end{array}$ & $\begin{array}{l}0.98 \\
202\end{array}$ \\
\hline $\begin{array}{l}\text { Cultural Diversity } \\
\text { Appreciation }\end{array}$ & $\begin{array}{l}\text { Mean } \\
\mathrm{n}\end{array}$ & $\begin{array}{c}0.68 \\
28 \\
\end{array}$ & $\begin{array}{c}0.60 \\
50 \\
\end{array}$ & $\begin{array}{c}0.63 \\
78 \\
\end{array}$ & $\begin{array}{c}0.87 \\
82 \\
\end{array}$ & $\begin{array}{l}0.95 \\
122 \\
\end{array}$ & $\begin{array}{l}0.92 \\
204 \\
\end{array}$ \\
\hline $\begin{array}{l}\text { Ideas, Events Western } \\
\text { Civilization }\end{array}$ & $\begin{array}{l}\text { Mean } \\
\mathrm{n}\end{array}$ & $\begin{array}{c}0.71 \\
28 \\
\end{array}$ & $\begin{array}{c}0.60 \\
50 \\
\end{array}$ & $\begin{array}{c}0.64 \\
78 \\
\end{array}$ & $\begin{array}{c}0.41 \\
80 \\
\end{array}$ & $\begin{array}{l}0.67 \\
121 \\
\end{array}$ & $\begin{array}{l}0.57 \\
201 \\
\end{array}$ \\
\hline $\begin{array}{l}\text { Ideas, Events } \\
\text { Other Cultures }\end{array}$ & $\begin{array}{l}\text { Mean } \\
\mathrm{n}\end{array}$ & $\begin{array}{c}0.36 \\
28 \\
\end{array}$ & $\begin{array}{c}0.53 \\
51 \\
\end{array}$ & $\begin{array}{c}0.47 \\
79 \\
\end{array}$ & $\begin{array}{c}0.50 \\
80 \\
\end{array}$ & $\begin{array}{l}0.63 \\
122 \\
\end{array}$ & $\begin{array}{l}0.58 \\
202 \\
\end{array}$ \\
\hline $\begin{array}{l}\text { Business Ethics \& } \\
\text { Moral Issues }\end{array}$ & $\begin{array}{l}\text { Mean } \\
\mathrm{n}\end{array}$ & $\begin{array}{c}1.25 \\
28 \\
\end{array}$ & $\begin{array}{c}1.08 \\
52 \\
\end{array}$ & $\begin{array}{c}1.14 \\
80 \\
\end{array}$ & $\begin{array}{c}1.35 \\
80 \\
\end{array}$ & $\begin{array}{c}1.40 \\
124 \\
\end{array}$ & $\begin{array}{l}1.38 \\
204 \\
\end{array}$ \\
\hline $\begin{array}{l}\text { Environmental } \\
\text { Issues }\end{array}$ & $\begin{array}{l}\text { Mean } \\
\mathrm{n}\end{array}$ & $\begin{array}{c}0.68 \\
28\end{array}$ & $\begin{array}{c}0.65 \\
52\end{array}$ & $\begin{array}{c}0.66 \\
80\end{array}$ & $\begin{array}{c}0.53 * * \\
81\end{array}$ & $\begin{array}{c}0.91 * * \\
124\end{array}$ & $\begin{array}{l}0.76 \\
205 \\
\end{array}$ \\
\hline $\begin{array}{l}\text { Global Issues } \\
\text { In Business }\end{array}$ & $\begin{array}{l}\text { Mean } \\
\mathrm{n}\end{array}$ & $\begin{array}{c}1.29 \\
28 \\
\end{array}$ & $\begin{array}{c}1.21 \\
52 \\
\end{array}$ & $\begin{array}{c}1.24 \\
80 \\
\end{array}$ & $\begin{array}{c}1.29 * \\
82 \\
\end{array}$ & $\begin{array}{c}1.49 * \\
124 \\
\end{array}$ & $\begin{array}{l}1.41 \\
206 \\
\end{array}$ \\
\hline $\begin{array}{l}\text { Develop Lifelong } \\
\text { Learning Skills }\end{array}$ & $\begin{array}{l}\text { Mean } \\
\mathrm{n}\end{array}$ & $\begin{array}{c}1.36 \\
28 \\
\end{array}$ & $\begin{array}{c}1.13 \\
52 \\
\end{array}$ & $\begin{array}{c}1.21 \\
80 \\
\end{array}$ & $\begin{array}{c}1.54 \\
82 \\
\end{array}$ & $\begin{array}{c}1.44 \\
124 \\
\end{array}$ & $\begin{array}{l}1.48 \\
206 \\
\end{array}$ \\
\hline $\begin{array}{l}\text { Business } \\
\text { Functional Areas }\end{array}$ & $\begin{array}{l}\text { Mean } \\
\mathrm{n}\end{array}$ & $\begin{array}{c}1.50 \\
28 \\
\end{array}$ & $\begin{array}{c}1.13 \\
52 \\
\end{array}$ & $\begin{array}{c}1.26 \\
80 \\
\end{array}$ & $\begin{array}{c}1.61 \\
82 \\
\end{array}$ & $\begin{array}{l}1.52 \\
124 \\
\end{array}$ & $\begin{array}{l}1.55 \\
206 \\
\end{array}$ \\
\hline $\begin{array}{l}\text { Expertise In } \\
\text { Major Field }\end{array}$ & $\begin{array}{l}\text { Mean } \\
\mathrm{n}\end{array}$ & $\begin{array}{c}0.54 \\
28 \\
\end{array}$ & $\begin{array}{c}0.77 \\
52 \\
\end{array}$ & $\begin{array}{c}0.69 \\
80 \\
\end{array}$ & $\begin{array}{c}1.32 \\
82 \\
\end{array}$ & $\begin{array}{l}1.41 \\
124 \\
\end{array}$ & $\begin{array}{l}1.37 \\
206 \\
\end{array}$ \\
\hline
\end{tabular}

$*$ Difference significant at $\mathrm{p}<0.05$

** Difference significant at $\mathrm{p}<0.01$

skills, quantitative and computer skills, and expertise in their major field. As previously noted, though positive, the ratings of cultural diversity, environmental, and historical and cultural perspective issues consistently lag behind the other educational outcomes items listed.

\section{Ability To Meet Or Exceed AACSB Educational Standards For Accreditation}

Most of the items listed in the "educational outcomes" section of the survey correspond to core learning goals identified as important by AACSB. While the accrediting agency does not set specific benchmarks or rating levels that must be achieved on each of these dimensions, it does require the college to demonstrate that it delivers on these goals in a quality fashion. The ratings on these items suggest that the college meets or exceeds this standard on all of the items. However, the ratings also divulge that there is room for improvement on items like cultural diversity 
awareness, cultural diversity appreciation, knowledge ideas and events from western civilization, environmental issues, and ideas and events from other cultures

Table 8 - Education Outcomes Averages by Major and Gender

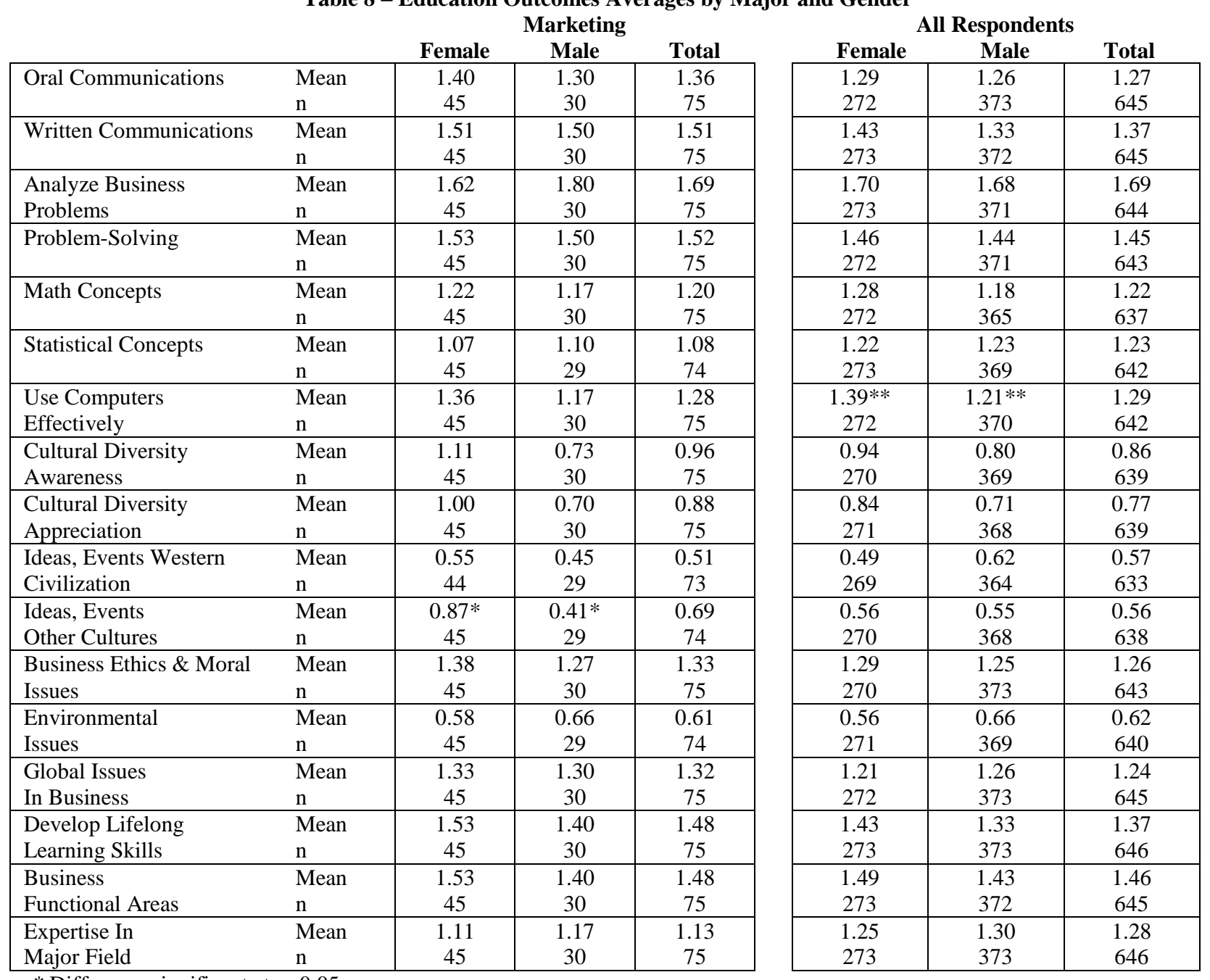

* Difference significant at $\mathrm{p}<0.05$

** Difference significant at $\mathrm{p}<0.01$

\section{Ability To Provide Students With A Flexible Curriculum That Is Able To React To Changes In The Business Community}

As changes are noted in demands of the business community and/or requirements for maintenance of AACSB accreditation, similar changes (or lack thereof) in student ratings of their educational outcomes and educational environment may be assessed. For example, if the Business Advisory Council or AACSB placed a priority on the importance of global issues in business, we would likely adapt the curriculum and educational delivery system to accommodate this request. An analysis of student ratings of the specific educational outcome (Global Issues in Business) over time would be one means of assessing the degree to which curriculum and delivery system alterations have been effective. Student ratings of several others of the educational outcomes and educational 
environment items would likely serve as helpful indicators of success or failure in curriculum/delivery system innovations.

\section{Additional Benefits}

While the survey does not directly address enrollment levels, it does help the college to evaluate student satisfaction with the business curriculum. The curriculum and its delivery define a substantial portion of the "product" purchased by students when they attend a college or university. Therefore, it is logical to assume that higher satisfaction levels will lead to more positive word of mouth in the marketplace. Additionally, well educated graduates are more likely to reinforce a positive reputation of the college among employers in the business community. Survey results can be used in promotional materials to demonstrate program effectiveness to prospective students, parents and other stake holders.

Finally, the results reported as "Educational Outcomes by Business Major and Gender" show how the data may be used to examine potentially interesting events and trends. Though these results may not appear to be directly related to our stated research objectives, they serve as an illustration of a partitioning of the data that enhances an assessment of results at the departmental level. As previously noted, these data should serve to motivate discussions and brainstorming sessions at the departmental level, and thus serve as a source of fresh ideas for curriculum and educational delivery system improvement initiatives.

\section{REFERENCES}

1. AACSB International - The Association to Advance Collegiate Schools of Business, Eligibility Procedures and Standards for Business Accreditation, (April, 2003, revised January, 2004).

2. Beverly A. Browne, Dennis O. Kaldenberg, William G. Browne and Daniel J. Brown, Student as Customer: Factors Affecting Satisfaction and Assessments of Institutional Quality, Journal of Marketing for Higher Education, Vol. 8, No. 3, pp.1-14, 1998.

3. Ronald L. Coccari and Rajshekhar G. Javalgy, Analysis of Student Needs in Selecting a College or University in a Changing Environment, Journal of Marketing for Higher Education, Vol. 6, No. 2, pp. 27 40, 1995.

4. Michael J. Conard and Maureen A. Conard, Factors that Predict Academic Reputation Don't Always Predict Desire to Attend, Journal of Marketing for Higher Education, Vol. 11, No. 4, pp. 27-40, 2001.

5. Frank J. Franzak and Deborah L. Cowles, Viewing the Curriculum as Product: Implications from a Marketing Research Study, Journal of Marketing for Higher Education, Vol. 4, No. 1/2, pp. 143-158, 1993.

6. Joseph G. Glynn and Richard A. Shick, Use Of A Real World Business Panel To Assist In MBA Program Outcomes Assessment And Curriculum Refinement, International Business and Economics Research Journal, Vol. 2, No. 4, pp. 51-62, 2003.

7. Matthew Joseph and Beatriz Joseph, Employers' Perception of Service Quality in Higher Education, Journal of Marketing for Higher Education, Vol. 8, No. 2, pp. 1-13, 1997.

8. Fahri Karakaya and Fera Karakaya, Employer Expectations from a Business Education, Journal of Marketing for Higher Education, Vol. 7, No. 1, pp. 9-16, 1996.

9. Hume Winzar and Ray Morley, Attitudinal and Environmental Influences on Preferences for Undergraduate Business Courses, Journal of Marketing for Higher Education, Vol. 5, No. 1, pp. 49-70, 1994.

10. Oliver H. M. Yau and Wayne Kwan, The Teaching Evaluation Process: Segmentation of Marketing Students, Journal of Marketing for Higher Education, Vol. 4, No. 1/2, pp. 309-323, 1993.

11. Raymond Zammuto, S.M. Keaveney, E. J. O'Connor, Rethinking Student Services: Assessing and Improving Service Quality, Journal of Marketing for Higher Education, Vol. 7, No. 1, pp. 45-70, 1996. 


\section{APPENDIX}

\section{Senior Outcomes Survey}

\section{Section 1}

Educational Outcomes. We are interested in determining how well your College education helped you develop strengths in a number of areas. Please read each of the statements below, and indicate your level of agreement or disagreement by circling a number in one of the adjacent boxes.

\begin{tabular}{|c|c|c|c|c|c|c|}
\hline My education has helped me to... & $\begin{array}{l}\text { Strongly } \\
\text { Disagree }\end{array}$ & $\begin{array}{l}\text { Slightly } \\
\text { Disagree }\end{array}$ & Neutral & $\begin{array}{l}\text { Slightly } \\
\text { Agree }\end{array}$ & $\begin{array}{l}\text { Strongly } \\
\text { Agree }\end{array}$ & $\begin{array}{l}\text { Not } \\
\text { Applicable }\end{array}$ \\
\hline develop my oral communication skills. & -2 & -1 & 0 & +1 & +2 & N/A \\
\hline develop my written communication skills. & -2 & -1 & 0 & +1 & +2 & N/A \\
\hline better analyze business problems. & -2 & -1 & 0 & +1 & +2 & N/A \\
\hline develop effective problem solving skills. & -2 & -1 & 0 & +1 & +2 & N/A \\
\hline understand basic mathematical concepts. & -2 & -1 & 0 & +1 & +2 & N/A \\
\hline understand basic statistical concepts. & -2 & -1 & 0 & +1 & +2 & N/A \\
\hline use computers effectively. & -2 & -1 & 0 & +1 & +2 & N/A \\
\hline $\begin{array}{l}\text { increase my awareness of cultural diversity } \\
\text { and demographic trends. }\end{array}$ & -2 & -1 & 0 & +1 & +2 & N/A \\
\hline $\begin{array}{l}\text { increase my appreciation of cultural diversity } \\
\text { and demographic trends. }\end{array}$ & -2 & -1 & 0 & +1 & +2 & N/A \\
\hline $\begin{array}{l}\text { become acquainted with the principal ideas } \\
\text { and historical events of western civilization. }\end{array}$ & -2 & -1 & 0 & +1 & +2 & N/A \\
\hline $\begin{array}{l}\text { become acquainted with the principle ideas } \\
\text { and historical events of other cultures. }\end{array}$ & -2 & -1 & 0 & +1 & +2 & N/A \\
\hline $\begin{array}{l}\text { better understand the ethical and moral issues } \\
\text { likely to confront business professionals. }\end{array}$ & -2 & -1 & 0 & +1 & +2 & N/A \\
\hline $\begin{array}{l}\text { develop an appreciation and concern for } \\
\text { environmental issues. }\end{array}$ & -2 & -1 & 0 & +1 & +2 & N/A \\
\hline $\begin{array}{l}\text { understand the importance of the impact of } \\
\text { global issues on the business community. }\end{array}$ & -2 & -1 & 0 & +1 & +2 & N/A \\
\hline develop life long learning skills. & -2 & -1 & 0 & +1 & +2 & N/A \\
\hline $\begin{array}{l}\text { develop a working knowledge of the } \\
\text { functional areas of business. }\end{array}$ & -2 & -1 & 0 & +1 & +2 & N/A \\
\hline $\begin{array}{l}\text { develop expertise with respect to my major } \\
\text { field. }\end{array}$ & -2 & -1 & 0 & +1 & +2 & N/A \\
\hline
\end{tabular}




\section{Section 2}

Educational Environment. We are interested in your evaluation of your college years at on a variety of dimensions. For each statement below, please indicate your level of agreement or disagreement by circling a number in one of the adjacent boxes..

\begin{tabular}{|c|c|c|c|c|c|c|}
\hline Additional Issues & $\begin{array}{l}\text { Strongly } \\
\text { Disagree }\end{array}$ & $\begin{array}{c}\text { Slightly } \\
\text { Disagree }\end{array}$ & Neutral & $\begin{array}{c}\text { Slightly } \\
\text { Agree }\end{array}$ & $\begin{array}{c}\text { Strongly } \\
\text { Agree }\end{array}$ & $\begin{array}{c}\text { Not } \\
\text { Applicable }\end{array}$ \\
\hline $\begin{array}{l}\text { Generally speaking, my business classes were } \\
\text { small in size. }\end{array}$ & -2 & -1 & 0 & +1 & +2 & N/A \\
\hline $\begin{array}{l}\text { I found that the library resources provided at } \\
\text { Canisius adequately supported my educational } \\
\text { activities. }\end{array}$ & -2 & -1 & 0 & +1 & +2 & N/A \\
\hline $\begin{array}{l}\text { The library was usually open during the days } \\
\text { and times I needed it. }\end{array}$ & -2 & -1 & 0 & +1 & +2 & N/A \\
\hline $\begin{array}{l}\text { The computer labs were usually open during the } \\
\text { days and times I need them. }\end{array}$ & -2 & -1 & 0 & +1 & +2 & N/A \\
\hline $\begin{array}{l}\text { The computer hardware provided in the } \\
\text { computer labs adequately supported my } \\
\text { educational activities. }\end{array}$ & -2 & -1 & 0 & +1 & +2 & N/A \\
\hline $\begin{array}{l}\text { The computer software provided in the } \\
\text { computer labs adequately supported my } \\
\text { educational activities. }\end{array}$ & -2 & -1 & 0 & +1 & +2 & N/A \\
\hline $\begin{array}{l}\text { I found that the writing assignments in my } \\
\text { business courses were a valuable part of my } \\
\text { education. }\end{array}$ & -2 & -1 & 0 & +1 & +2 & N/A \\
\hline $\begin{array}{l}\text { I found that the analytical assignments (e.g. } \\
\text { case studies, problem solving exercises) in my } \\
\text { business courses were a valuable part of my } \\
\text { education. }\end{array}$ & -2 & -1 & 0 & +1 & +2 & N/A \\
\hline $\begin{array}{l}\text { I found that the group projects in my business } \\
\text { classes were a valuable part of my education. }\end{array}$ & -2 & -1 & 0 & +1 & +2 & N/A \\
\hline $\begin{array}{l}\text { I found it valuable when professors used their } \\
\text { experiences in the business community to } \\
\text { illustrate business concepts and theories. }\end{array}$ & -2 & -1 & 0 & +1 & +2 & N/A \\
\hline $\begin{array}{l}\text { I found it valuable when professors discussed } \\
\text { their academic research in class. }\end{array}$ & -2 & -1 & 0 & +1 & +2 & N/A \\
\hline $\begin{array}{l}\text { I found that my business professors were } \\
\text { committed to helping me get a good education. }\end{array}$ & -2 & -1 & 0 & +1 & +2 & N/A \\
\hline $\begin{array}{l}\text { I found that the career placement center } \\
\text { provided valuable resources and services to } \\
\text { assist me in my search for a job. }\end{array}$ & -2 & -1 & 0 & +1 & +2 & N/A \\
\hline
\end{tabular}

\section{Please turn to the last page}


Section 3

Additional Information. The following information will help us compare your answers with graduates who are similar to you.

What was your major(s)? (Dual majors check both areas).

\begin{tabular}{|l|l|l|l|}
\hline$\square$ Accounting & $\square$ Economics & $\square$ Finance & $\square$ Entrepreneurship \\
\hline$\square$ AIS & $\square$ Information Systems & $\square$ International Business & $\square$ Management \\
\hline$\square$ Marketing & & & \\
\hline
\end{tabular}

Gender
Female
$\square \quad$ Male

Thank you for your help!

WSB survey form 100100051468

\section{NOTES}

